\title{
THE USE OF AUDIO-VISUAL LEARNING MEDIA IN IMPROVING STUDENT CONCENTRATION IN ENERGY MATERIALS
}

\author{
Nia Karlina ${ }^{1}$ Ruli Setiyadi ${ }^{2}$ \\ ${ }^{1}$ SDN Babakan Loa \\ ${ }^{2}$ IKIP Siliwangi \\ ${ }^{1}$ nengniakarlina@gmail.com, ${ }^{2}$ setiadiruli@gmail.com
}

\begin{abstract}
Learning Natural Sciences is learning done in elementary schools. During this time, science learning was still difficult for most teachers and prospective elementary school teachers. These difficulties include the difficulties of students in remembering subject matter due to the lack of suitable learning media. In the learning process, teachers should use learning media that can increase students' concentration on the material, in this case, the use of audio-visual media. The purpose of this study was to analyze the difficulties experienced by teachers and prospective teachers in the matter of learning natural science materials. The research method used is quantitative descriptive research method. The study population was 25 elementary school students. The method of data collection is to conduct evaluations conducted in several classroom action research cycles. Classroom learning methods are done classically, students learn by cooperative learning methods. The results showed that audio-visual learning media can be utilized optimally to help students achieve learning goals, and the use of audiovisual learning media is basically intended to make learning activities more effective in learning goals can be achieved well.
\end{abstract}

Keywords: Learning Media, audio-visual, memory.

\begin{abstract}
Abstrak
Mata pelajaran IPA adalah salah satu mata pelajaran yang diajarkan di sekolah dasar. Selama ini beberapa materi pelajaran IPA masih dianggap sulit oleh sebagian besar guru dan siswa-siswi sekolah dasar. Kesulitan-kesulitan ini termasuk kesulitan para siswa dalam mengingat materi pelajaran dikarenakan kurangnya media pembelajaran yang cocok, dan juga kurang variatifnya guru dalam menentukan metode atau pendekatan yang digunakan dalam proses pembelajaran IPA. Guru sebaiknya menggunakan media pembelajaran yang mampu meningkatkan konsentrasi siswa, dalam hal ini adalah penggunaan media audio visual pada pembelajaran IPA. Tujuan dari penelitian ini adalah untuk menganalisis berbagai kesulitan yang dialami oleh para guru dan siswa-siswi dalam hal pembelajaran IPA. Metode penelitian yang digunakan adalah metode penelitian deskriptif kuantitatif. Populasi dalam penelitian ini adalah siswa-siswi kelas IV yang berjumlah 25 orang. Metode pengambilan data adalah dengan penelitian tindakan kelas dalam beberapa siklus. Metode pembelajaran dilakukan secara klasikal, para siswa belajar secara cooperative learning. Hasil penelitian menunjukkan bahwa media pembelajaran audio visual dapat dimanfaatkan secara maksimal untuk membantu meningkatkan konsentrasi siswa secara signifikan, dan pemanfaatan media pembelajaran audio visual pada dasarnya dimaksudkan agar kegiatan pembelajaran lebih efektif sehingga tujuan pembelajaran dapat tercapai dengan baik.
\end{abstract}

Kata Kunci: Media Pembelajaran, audio visual, daya ingat.

\section{INTRODUCTION}

Learning is the process of interaction between individuals with learning resources that results in a change in behavior. Gagne (Najib 2010: 5) reveals learning is a process of behavioral change that includes changes in human tendencies, such as attitudes, interests, or values and changes in abilities, namely an increase in the ability to perform various types of performance. Changes in behavior must be able to serve for a certain period of time. Thus, 
learning can basically be seen as a process of positive-qualitative change that occurs in students' behavior as subjects due to an increase in knowledge, skills, values, attitudes, interests, appreciation, ability to think logically and critically, interactive abilities, and creativity that has been achieved. or permanent. This also applies to every individual who carries out the learning process both in the family or school.

The learning process that occurs in schools is a process of interaction between teachers and students. Teachers are individuals who are responsible for educating, teaching, and directing students to be able to master certain competencies. As an educator, teachers are required to have various competencies. In Law No. 14 of 2005 article 10 concerning Teachers and Lecturers (Asrori 2012: 1) stated that teacher competencies include pedagogic competence, personality competence, social competence, and professional competence. These competencies become guidance for teachers in educating and teaching students.

The reality in the field shows that in carrying out classroom learning, teachers often have obstacles that can affect the quality of learning. In the end, teaching and learning activities become less effective and efficient. This can be caused by various factors, both factors related to the teacher and students. Both of these factors basically influence learning outcomes, because even though these two factors are objects of learning.

Factors related to the teacher can be caused by the lack of insight and knowledge of teachers in the teaching method, the selection of learning media that lacks interest and motivation of students to learn, inappropriate learning approaches, lack of teacher creativity and innovation in learning, weak management of teachers in learning, and so forth. While the factors caused by students, among them: lack of memory of students to the material that has been taught, the ability of students below average, lack of interest and motivation of students in learning, student attention is often disturbed, student maturity in learning has not been formed, and willingness students to study seriously are still low. This phenomenon if not immediately addressed will have a negative impact on student learning outcomes so that the quality of education will be lower. Thus, the teacher as a scenario holder in learning must immediately find alternative solutions so that these weaknesses can be overcome as optimally as possible.

According to the Education Unit Level Curriculum (2006: 13) Science is "how to systematically find out about nature, so that the Science is not just mastery of a collection of knowledge in the form of facts, concepts, or principles but also a process of discovery". Furthermore, Nash (Samatowa, 2006: 2) suggested the understanding of Natural Science, 
namely: A method or method that observes nature, the way science observes this world is analytical, careful, and connects one phenomenon with another so that the whole forms a new perspective on the object he observed.

In Permendiknas No.22 of 2006 concerning the Content Standards put forward regarding the understanding of the Natural Science, which is IPA "is knowledge related to how to systematically find out about nature, so that the IPA is not only mastering a collection of knowledge in the form of facts, concepts, or principles only but also a process of discovery ". Of the several definitions put forward by these experts, it can be concluded that natural science or science is the science that studies the universe and its contents and the events that occur in it are based on scientific processes.

The results of observations conducted by researchers in the field indicate that basically teachers rarely use learning media, they are only fixated on the method of lecturing, discussion, question, and answer, or just assignment. In the end, student learning achievement is low and learning is less meaningful. This is as happened in Class IV SDN Babakan Loa, Padalarang Subdistrict, West Bandung Regency, 2017-2018 school year, which shows that the average value of the science study area only reaches (55.62). This is due to various factors, including: (i) in general the methods used by the teacher are lecture and discussion methods; (ii) teachers rarely use instructional media in teaching them; (iii) teacher creativity and innovation does not develop; and (iv) the guidance system for teachers is uneven.

Based on this phenomenon, it is not surprising that the quality of science learning is low and in the end, student learning outcomes are not optimal. Firdaus (2015) suggested that energy learning in elementary school was not optimal. For this reason, there needs to be awareness from various parties, especially teachers, that new innovations are needed so that learning outcomes can improve.

In science learning, especially about energy material, something concrete is needed. Learning Energy in PrimaryTherefore, in the process of teaching and learning about energy needs to be used learning media. With the existence of these media, students will learn directly about a phenomenon so as not to verbalism. That is, they feel, implement, and ultimately understand because they are directly involved in the learning process.

There are two variables that become the material in this study, namely the dependent variable in the form of student concentration in the learning process of science, while the independent variable is in the form of visual audio media used in science learning in the classroom. 
Based on the description above, the authors are interested in conducting classroom action research with the title "Use of Audio-Visual Learning Media to Improve Science Learning Outcomes about Energy (Classroom Action Research in Babakan Loa Elementary School Class IV Semester II 2017 Academic Year -2018 Padalarang District, West Bandung Regency) ".

\section{METHOD}

This type of research is Classroom Action Research. This research is reflective by taking certain actions in order to improve or improve the practices of classroom learning in a more professional manner.

Classroom Action Research has a very important and strategic role to improve the quality of learning if it is implemented properly and correctly Kusnandar, (2009). In this study, the authors carried out action research to improve children's learning concentration by playing motor sensory. For that class action is carried out in two cycles, each cycle includes four stages of activities, namely: 1) Planning, 2) Action, 3) Observation, and 4) Reflection.

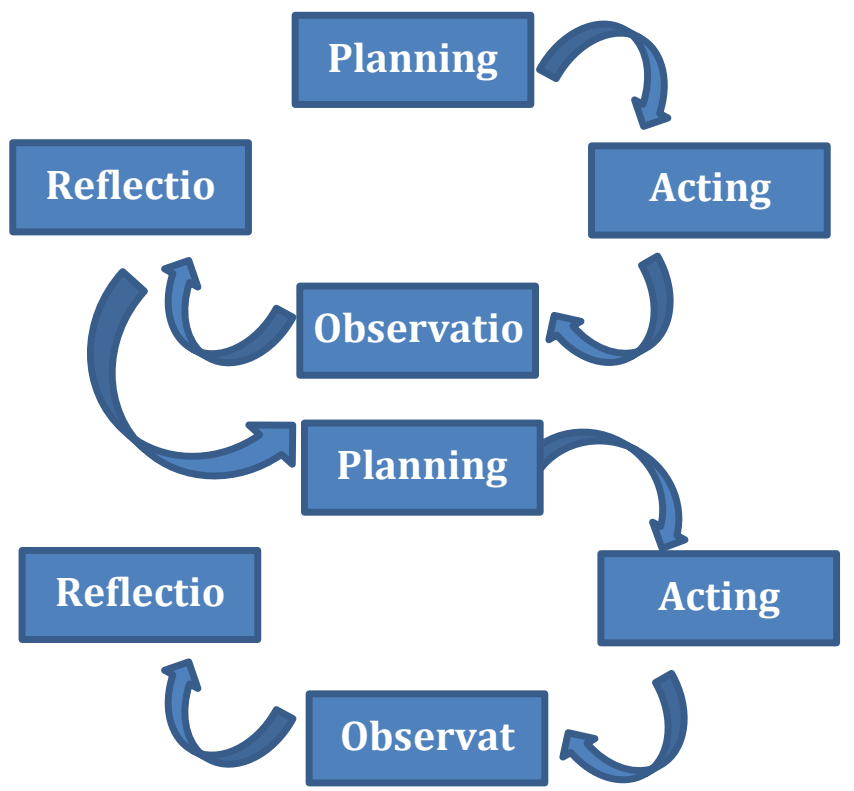

Figure 1. Class Action Research Cycle. Source: (Arikunto, 2010: 17)

As explained in the previous chapter that in this study the author uses audio-visual learning media in an effort to improve student learning outcomes of Class IV students of energy material, with the assumption that by using audio-visual media the science learning material of abstract energy can be more easily remembered by students use of these media, this is because the learning media with audio-visual media are able to convey information or material that is difficult and able to stimulate their visibility and hearing of the material so that learning will be more effective because students' concentration becomes more increased. 


\section{RESULTS AND DISCUSSION}

This initial observation was used to find out the learning process of students about the learning of natural matter-energy science. This study begins with the observation of researchers collaborating with the fourth-grade teacher of SD Negeri Babakan Loa on the learning process of science, especially in energy material. This observation is carried out to find out the comparison of students' concentration results before and after using audio-visual. From the results of these observations obtained an overview of the learning process before the action is carried out. When learning takes place, most students are preoccupied with their own games and some even joke with other students, thus affecting the students' learning concentration. The media and teaching methods applied by the teacher are also still monotonous, making students feel bored and less interested in taking lessons so that only a small percentage of students pay attention when the teacher explains.

Students' concentration and understanding in listening to the story are still low. This is indicated by the few students who answer or respond when the teacher asks about energy material, and also the students' difficulties when asked to explain again what they have heard. Furthermore, on February 19, 2018, researchers conducted initial data collection as an illustration of students' concentration on learning. Of the 25 students who were recorded in the fourth grade of SD Negeri Babakan Loa, all took the pre-action test. Furthermore, it can be obtained that the average score of student concentration is in a Low category. There are 15 students who are in the low category, 8 students in the medium category, and 2 students in the high category. Overall, it can be concluded that the average activeness of fourth-grade students of Babakan Loa Elementary School belongs to the "Low" category. This is caused by a monotonous and boring learning approach.

Based on the description, it can be concluded that the problem faced by teachers in natural science learning is the lack of concentration of students in learning because the use of learning media is less varied so that it has an impact on the low ability of students in understanding the material presented by the teacher.

To overcome these problems, researchers try to solve it by trying to apply learning media that can involve students actively in learning, namely by applying science learning using Audio-visual. Learning science using Audio-visual is chosen because the teacher can see directly the activity of students in carrying out learning activities so that it will increase students' concentration on the subject matter delivered. 
The classroom action research conducted through these two cycles is conducted to find out whether using Audio-visual learning media can improve the concentration of natural science learning for fourth-grade students at Babakan Loa Elementary School, Padalarang District, West Bandung Regency.

From the results of the study student concentration based on the results of observations starting from the initial score (Pre Cycle) before the action is taken and after the action in Cycle I and cycle II. there has been a significant improvement, this can be seen as an increase in the score of student learning concentration in improving learning from the beginning before the action is carried out which is 1.9 fewer categories, increasing cycle I to 2.3 medium categories, and an increase back to cycle II to 3 high category.

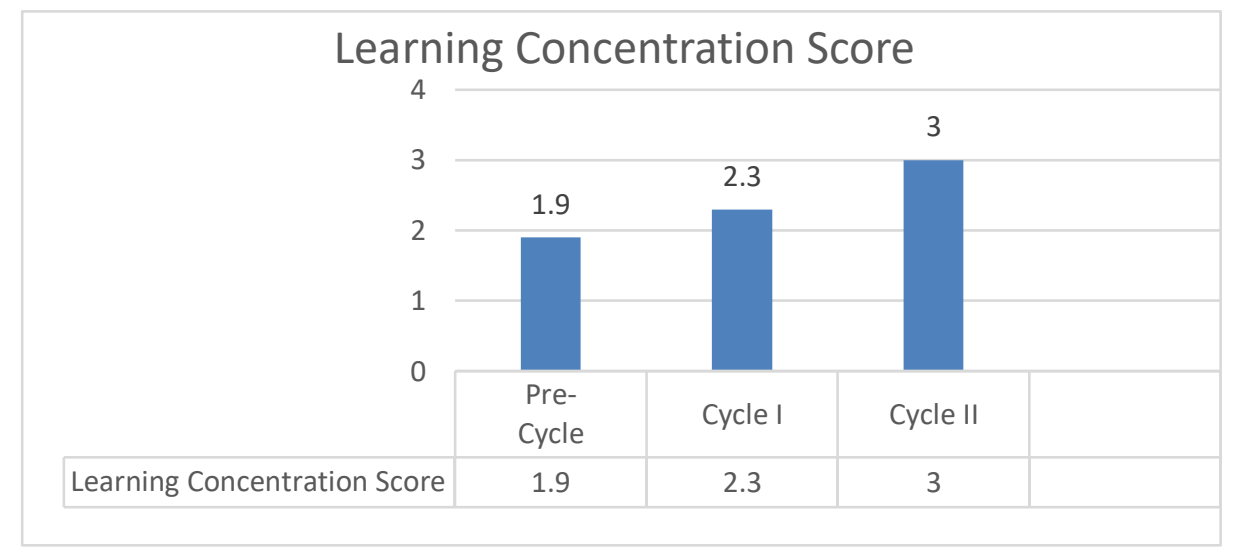

Figure 2. Graph of Learning Concentration Score

As for the percentage of observations of students' learning concentrations during science learning in energy material using Audio-visual learning media in pre-cycle, cycle I and Cycle II can be seen from the following table.

Table 1. Percentage of Increased Student Learning Concentration Based on Observations

\begin{tabular}{clccc}
\hline No & $\begin{array}{c}\text { Activity } \\
\text { Data }\end{array}$ & $\begin{array}{c}\text { Percentage } \\
\text { Pre cycle }\end{array}$ & $\begin{array}{c}\text { Percentage } \\
\text { Cycle I }\end{array}$ & $\begin{array}{c}\text { Percentage } \\
\text { Cycle II }\end{array}$ \\
\hline 1 & High & $8 \%$ & $12 \%$ & $64 \%$ \\
2 & Midle & $32 \%$ & $50 \%$ & $28 \%$ \\
3 & Low & $60 \%$ & $38 \%$ & $8 \%$ \\
\hline
\end{tabular}

The results in the graph above show that student learning concentration has increased from pre-cycle, cycle I and cycle II. In cycle I student learning concentration increased, namely in the pre-cycle of $8 \%$ in the high category, and in the first cycle increased to $12 \%$ in the high category. While at the second cycle meeting, it was $64 \%$ high category. Student learning concentration during learning can be seen in the following information. 
Observation results in the first cycle have increased. This can be seen from the ongoing learning process. The concentration of student learning while following the learning process begins to increase. Students who were still rowdy in the learning process became concentrated in taking lessons. Student learning concentration can be seen from the number of students who ask and raise their hands to answer questions from the teacher during learning. Students also look more eager to take science lessons on energy material, especially when asked to listen to videos with audio-visual learning media. Students also have a better understanding and understanding of energy elements. But some students still joked with their friends. Teachers also pay attention and guide students who are still noisy in learning.

The results of observations in cycle II show that students' learning concentration has increased. Student learning concentration also increased as shown by the increasing number of students who asked, and raised their hands to answer questions from the teacher. According to researchers' observations, at the time before students enter the class, many students are playing with their friends. In this second cycle meeting, students experience an increase in student concentration both in responding to the material, student involvement in learning, and student activity in the learning provided by the teacher. At this meeting, most of the students in the science learning material for energy were very good. Almost all students can quickly and precisely find elements of energy and types of energy. The students also looked very enthusiastic and enthusiastic in following the learning process.

At this second cycle meeting, there were still two students who had not yet completed. The constraints that led to the incompleteness of the two students were low attention and the ability to accept learning material that was slower than other friends. This can be deduced from the reasons for the two students. When the teacher asks students about what difficulties are still being experienced, the first student says if the video is shown too fast, while the second student argues that the learning material is too much.

This proves that the use of learning media in giving material influences students' understanding and classroom atmosphere in learning. In this study, audio-visual learning media proved to be able to help improve the concentration of learning for students. Increasing the concentration of student learning in the product is indicated by the acquisition of the average score of students from the pre-cycle, the action of the cycle I, the action of cycle II which uses audio-visual learning media. The acquisition of the average score of students' learning concentration using audio-visual learning media in science subjects of energy material in the pre-cycle average score of 1.9 with the percentage of the number of students who reached the 
high category by $8 \%$. While in cycle I experienced an increase in the average value of 1.9 to 2.3 which also increased the percentage of the number of students who reached the high category of $12 \%$ and in the second cycle also experienced an increase in the average score of 2.3 to 3 which also increases the percentage of the number of students who reach a high category score of $64 \%$.

Based on the results obtained in each cycle, it can be said that this research has succeeded in achieving the predetermined indicator that is achieving a score of 3 with a high learning concentration category of students who received a score of 2 from the number of students, so this study was stopped in cycle II.

The increased concentration of student learning that has been experienced by students as described in the results of research and discussion above, proved that using audio-visual learning media is considered successful and can increase student concentration in learning science.

\section{CONCLUSION}

Based on the research results obtained as described in Chapter IV, it can be concluded as follows:

1. Audio-visual learning media can improve student learning concentration so that the acquisition of students' grades in natural science subjects on Earth and celestial objects can increase significantly

2. As a learning resource, audio-visual learning media must be able to be utilized optimally to help students achieve learning goals;

3. The use of audio-visual learning media is basically intended to help so that learning activities are more effective at achieving goals and efficient in terms of energy, time and cost;

4. Audio-visual learning media not only serves as teaching aids but can also act as a messenger for learning; and

5. On the other hand, the media is only a tool, behind the tool is a teacher who still has a central role in the learning process.

\section{ACKNOWLEDGMENTS}

Researchers want to say thank you as much as possible to the Supervisor who has provided input to the author in compiling the report of this research, To the Head of SDN Babakan Loa, Teachers and Students of grade IV, who have helped in the implementation of 
Journal of Elementary Education

Volume 3, Number 1, February 2019
P-ISSN: 2580-9326

E-ISSN: 2580-7714

this research, also to all parties who have been involved in this research. Hopefully, the results of this study will be useful for the world of education in Indonesia.

\section{REFERENCES}

Arikunto, Suharsimi. (2010). Penelitian Tindakan Kelas. Jakarta: Bumi Aksara.Arikunto, Suharsimi. (2010). Penelitian Tindakan Kelas. Jakarta: Bumi Aksara.

Arsyad, Azhar. (2011). Media Pembelajaran. Jakarta: PT Raja Grafindo Persada.

Baharudin and Esa Nur Wahyuni. (2010).Teori Belajar dan Pembelajaran. Yogyakarta: ArRuzz Media.

Budi, W. (2008). Ilmu Pengetahuan Alam. Surakarta: CV Putra Nugraha.

Depdiknas. (2006). Kurikulum Tingkat Satuan Pendidikan (KTSP). Jakarta: Departemen Pendidikan Nasional.

Depdiknas. (2006). Permendiknas No 22 Tahun 2006 Tentang Standar Isi. Jakarta: Depdiknas.

Dimyati and Mudjiono. (2013). Belajar dan Pembelajaran. Jakarta: Rineka Cipta.

Firdaus, A R. (2015). Penerapan Metode Eksperimen Untuk Meningkatkan Hasil Belajar Siswa Pada Materi Energi. Universitas Pendidikan Indonesia: Jurnal Pedagogik Pendidikan Dasar. (60-69)

Hakim, T. (2002). Mengatasi Gangguan Konsentrasi. Jakarta: Puspa Swara.

Hamalik, O. (2005). Metoda Belajar dan Kesulitan-Kesulitan Belajar. Bandung: Tarsito.

Kusnandar. (2009). Langkah Mudah Penelitian Tindakan Sebagai Pengembangan Profesi Guru. Jakarta: Rajawali Press.

Makmun, A S. (2005). Psikologi Kependidikan Perangkat Sistem Pengajaran Modul. Bandung: Remadja Rosdakarya.

Nugroho, W. (2007). Belajar Mengatasi Hambatan Belajar. Surabaya: Prestasi Pustaka

Rohani, A. (2010). Pengelolaan Pengajaran Sebuah Pengantar Menuju Guru Profesional. Jakarta: Rineka Cipta.

Samatowa, U. (2006). Bagaimana Membelajarkan IPA di Sekolah Dasar. Jakarta: Direktorat Pendidikan Nasional.

Sardiman. (2007). Interaksi \& Motivasi Belajar Mengajar.Jakarta: Raja Grafindo Persada.

Slameto. (2003). Belajar dan Faktor-Faktor yang Mempengaruhinya. Jakarta: PT Rineka Cipta.

Sumiati. (2012). Metode Pembelajaran. Bandung : CV Wacana Prima.

Susilana, R. (2012). Media Pembelajaran. Bandung: CV Wacana Prima 
Thohir, Khafidin, Dkk. Peningkatan Konsentrasi Belajar Menggunakan Metode Problem Solving, Universitas Muhammadiyah Purworejo, Purworejo

Tim Pengembang Ilmu Pendidikan FIP-UPI. (2012). Ilmu dan Aplikasi Pendidikan (Vol 2). Bandung: PT Imperial Bhakti Utama. 